\title{
Gastric Soft Tissue Neoplasm
}

National Cancer Institute

\section{Source}

National Cancer Institute. Gastric Soft Tissue Neoplasm. NCI Thesaurus. Code C5487.

A benign, intermediate, or malignant mesenchymal neoplasm that arises from the stomach. 